ROCZNIKI TEOLOGICZNE

Tom LXVII, zeszyt $11-2020$

DOI: https://doi.org/10.18290/rt206711-4

KS. MARIAN ZAJĄC

NAWRÓCENIE JAKO WARUNEK POJEDNANIA Z BOGIEM

\author{
CONVERSION AS A CONDITION FOR RECONCILIATION WITH GOD
}

\begin{abstract}
This article stems from the narrative contained in the Post-Synodal Apostolic Exhortation Reconcilatio et paenitentia of Saint John Paul II, who strongly warned Christians against losing their sense of sin. The work consists of three parts. The first one presents the main causes of the loss of the sense of $\sin$ in the modern world, and a catechetical strategy that calls for making a distinction between sinners and their sins and misconduct in order to attain true reconciliation. In the second part, an attempt will be made to justify the need to combat moral misconduct, which may result either from mere negligence or spiritual indifference. The author explains that $\sin$ is an obvious disturbance of the objective order of God, caused by a free and conscious act of man, that exists in the world. Also, it will be highlighted that there still exists a process of temptation to sin by the significant forces of evil; this process weakens the ability to be converted. Moreover, the five-stage process of sinfulness is described. The third part will explain why man's personal conversion is a necessary element of forgiveness. Although only God can truly forgive guilt and wrongdoing by giving man His grace, still forgiveness is necessary as a prerequisite for the proper development and maturation of the human person. The article ends with a reflection that without conversion and the ability to forgive there is no true human community, much less a Christian community.
\end{abstract}

Keywords: conversion; reconciliation; sin; God.

W posynodalnej adhortacji apostolskiej Reconcilatio et paenitentia św. Jan Paweł II przestrzegał przed groźnym zjawiskiem, jakie pojawiało się w zlaicyzowanym świecie, a które polega na „utracie poczucia grzechu” oraz zdolności

Ks. prof. dr hab. MARIAN ZAJĄC, Katedra Katechetyki Integralnej Wydziału Teologii KUL; adres do korespondencji: Al. Racławickie 14, 20-950 Lublin; e-mail: mzajac@kul.pl; ORCID: https://orcid.org/0000-0002-2940-5154. 
do nawrócenia (por. RP 18) ${ }^{1}$. To zagadnienie jest coraz bardziej widocznie w refleksjach teologów, którzy utrzymują, że dzisiejsza cywilizacja nacechowana jest wręcz negacją grzechu², a Kościół katolicki nie ma już nad ludźmi młodymi rządu dusz ${ }^{3}$ i w demokratycznym społeczeństwie „nie on ustala standardy i wzory zachowań"4 . Chcąc jednak ratować wszystko to, co możliwe jest do uratowania „przyjmuje coraz częściej język, styl, warunki narzucane przez dominujące modele popkultury" ". Czyni to w nadziei, że zastosowany kod kulturowy pozwoli na utrzymanie duszpasterskiego kontaktu z tymi, którzy chcą się radykalnie wyemancypować spod jego duchowej kurateli ${ }^{6}$. Ale taka strategia może doprowadzić do tego, że wartości, które zamierza ocalić, szczególnie te podkreślające rolę wiary w Boga rodzącej w człowieku poczucie niewystarczalności i pozwalającej oszacować znaczenie grzechu, tracą szczególnie wśród ludzi młodych na swojej aktualności ${ }^{7}$. Wydaje się natomiast, że próba ocalenia sacrum dla współczesnej kultury i człowieka musi dotykać najdrażliwszych miejsc współczesnego świata, czyli poczucia grzechu oraz indywidualnej odpowiedzialności człowieka przed Bogiem wyrażającej się w postawie nawrócenia.

Oficjalne nauczanie Kościoła w tej sprawie podkreśla słuszność wszelkich starań, które zmierzają do wyjaśnienia psychologicznej i teologicznej tajemnicy grzechu ${ }^{8}$. Jednakże „Kościół ma obowiązek przypomnienia wszystkim uczonym zajmującym się tą dziedziną, z jednej strony o konieczności pozostania wiernym Słowu Bożemu, które poucza nas także o grzechu, z drugiej - o ryzyku przyczynienia się do jeszcze większego osłabienia we współczesnym świecie poczucia grzechu" (RP 17). Tymczasem nawrócenie poszczególnych osób oraz

\footnotetext{
${ }^{1}$ JAN PAWEŁ II, Adhortacja apostolska o pojednaniu i pokucie w dzisiejszym posłannictwie Kościoła Reconciliatio et paenitentia (2.12.2007), AAS 77 (1985), s. 267 [dalej: RP].

${ }^{2}$ Por. J. NAGÓRNY, Zanik poczucia grzechu w świecie wspótczesnym, „Kurier Synodalny” 22(1996),

${ }^{3}$ Por. P. MĄKOSA, Między katolicka ortodoksja a indywidualizacją wierzeń dorosłych Polaków, w: Katechetyk $i$ wychowawca, Warszawa 2019, s. 300.

${ }^{4}$ J. SNOPEK, Wstęp, w: Religijność w dobie popkultury, red. T. Chachulski, J. Snopek, M. Ślusarska, Warszawa 2014, s. 8.

${ }^{5}$ Tamże.

${ }^{6}$ Por. A. SzUBARTOWSKA, Zmiana kodu kulturowego młodzieży wyzwaniem dla katechety szkolnego, w: Katecheza w szkole współczesnej, red. M. Zając, Lublin 2010, s. 45.

${ }^{7}$ Por. A. Jasnos, Mój Bóg, Lublin 2020, s. 17.

${ }^{8}$ „Grzech to wolna, egzystencjalna i radykalna decyzja przeciwstawienia się woli Bożej wyrażającej się w porządku natury i łaski oraz w słowie objawionym" - K. RAHNER, H. VORGRIMLER, Mały słownik teologiczny, tłum. T. Mieszkowski, P. Pachciarek, Warszawa 1987, s. 132.
} nr 1, s. 10. 
wspólnot stanowi warunek pojednania z Bogiem, które prowadzi do zbawienia ${ }^{9}$. $\mathrm{Z}$ potrzeby przypomnienia tej problematyki wyrasta niniejszy artykuł.

\section{PRZYCZYNY UTRATY POCZUCIA GRZECHU I POTRZEBY NAWRÓCENIA}

Ewangelista Jan przekazał charakterystyczne przesłanie: „Jeśli mówimy, że nie mamy grzechu, to samych siebie oszukujemy i nie ma w nas prawdy" (1 J 1,8). Owo „oszukiwanie siebie” wynika z faktu, że jeśli ktoś nie wierzy w Boga, to automatycznie nie czuje się grzesznikiem, ponieważ sam ustala, co jest dobrem, a co złem. Wtedy wystarczy mu prosty fortel, jakim jest przestrzeganie prawa państwowego. Także człowiek, który powierzchownie wierzy w Boga, nie ma poszczucia grzechu, gdyż zadowala się tzw. porządnym życiem, wolnym od spektakularnych nieporządków moralnych ${ }^{10}$.

Chrześcijanie, którzy przyjmują Boga jako wyznacznik dobra i zła, wiedzą, że są wezwani, by „być doskonałymi jak Ojciec niebieski” (Mt 5,48). Ponieważ jest to zadanie bardzo wymagające, w jego realizacji człowiek wierzący nigdy nie zagłuszy w sobie poczucia grzechu oraz wyrzutów sumienia, które gwarantują duchowy postęp i otwierają na Boże miłosierdzie. Papież Franciszek w adhortacji apostolskiej Christus vivit apeluje o właściwe rozumienie grzechu i nawrócenia i tak naucza: „W tej perspektywie zasadnicze znaczenie ma odróżnienie grzesznika od jego grzechu i jego przewinienia, aby osiągnąć prawdziwe pojednanie. Oznacza to, że nienawidzisz zła, które wyrządza ci drugi, ale nadal go kochasz, ponieważ uznajesz jego słabość i widzisz w nim obraz Boga" (ChV 165) ${ }^{11}$.

W dokumencie Papieskiej Komisji Biblijnej można odnaleźć stwierdzenie, że współczesny człowiek, zarówno jako jednostka oraz członek wspólnoty staje wobec licznych problemów moralnych „które rozwój ludzkich nauk z jednej strony i globalizacja komunikacji z drugie strony stawiają stale w centrum zainteresowania do tego stopnia, że nawet ludzie faktycznie wierzący mają wrażenie, jakby niektóre pewniki z dawnych czasów zostały anulowane" ${ }^{12}$. Dotyczy

\footnotetext{
${ }^{9}$ Por. A. Dulles, Blask wiary. Wizja teologiczna Jana Pawła II, tłum. A. Nowak, Kraków 2003, s. 167. W takim stylu nauczał niezmiennie św. Jan Paweł II.

${ }^{10}$ Por. T. Lasconi, Ja i Ty przez 365 dni (+1), thum. K. Wilewska, Poznań 2007, s. 71.

${ }^{11}$ FranCISZEK, Posynodalna adhortacja apostolska Christus vivit do młodych i całego Ludu Bożego, wyd. polskie, Kraków 2019, nr 165 [dalej: ChV].

12 PAPIESKa Komisja BiBlijna, Biblia a moralność. Biblijne korzenie postępowania chrześcijańskiego, thum. R. Rubinkiewicz, Kielce 2009, nr 92, s. 31.
} 
to szczególnie poczucia grzechu i rozprzestrzeniania się wrażenia o indywidualnej bezgrzeszności współczesnego człowieka.

Psalmista zanotował jednak dramatyczną prośbę biblijnego człowieka, który od zawsze doświadczał swojej grzeszności i wtedy wołał do Boga: „W ogromie swego miłosierdzia wymaż moją nieprawość" (Ps 51,3). Tymczasem Tonino Lasconi, autor licznych publikacji poświęconych formacji chrześcijańskiej i wzrastaniu w wierze argumentuje, że zanik poczucia grzechu, który uniemożliwia wychowywanie w wierze dzieci, młodzieży i dorosłych spowodował, że dzisiaj w odczuciu ludzi grzech jest zawsze cudzy, a katalog potencjalnych winowajców jest bardzo rozbudowany. Wytworzyło się bowiem przekonanie, że grzech zależy nie od złej woli człowieka, ale od trudnego dzieciństwa, od zdemoralizowanego środowiska, od złych przyjaciół, którzy sprowadzili na manowce, od otrzymanego wychowania, od księdza, który zaszczepił poczucie winy, od papieża, który nie dostosowuje moralności do sondaży, od telewizji przepełnionej gwałtem i seksem, od związków zawodowych, które twierdzą, że wina jest po stronie złego pracodawcy, od feministek, które odebrały kobietom pokorę i wstyd, czy wreszcie od socjologów, psychologów, psychoanalityków, którzy uczą, że grzech nie istnieje ${ }^{13}$. Tymczasem, kto nie umie powiedzieć: „,moja nieprawość", nie może się nawrócić i nie może prosić o przebaczenie, czyli nie może być zbawiony. Taka jest trwająca nieprzerwanie od początku chrześcijaństwa tradycja pokutna Kościoła oparta na przekazie ewangelicznym ${ }^{14}$.

Wnikliwą analizę tej problematyki przeprowadził św. Jan Paweł II we wspomnianej wyżej adhortacji apostolskiej o pojednaniu i pokucie w dzisiejszym posłannictwie Kościoła. Uważa on, że poczucie winy, czyli świadomość grzechu jako realnie możliwej i faktycznie pojawiającej się rzeczywistości w ludzkim $\dot{z ̇ y c i u}^{15}$ ma swoje ostateczne źródło w świadomości moralnej człowieka i jest jakby jej termometrem. Zdaniem papieża powiązane jest to z tzw. poczuciem Boga, ponieważ wypływa ze świadomego stosunku łączącego człowieka z Bogiem jako jego Stwórcą, Panem i Ojcem (por. RP 18). Wymazanie poczucia

\footnotetext{
${ }^{13}$ Por. T. Lasconi, Ja i Ty przez 365 dni, s. 72.

14 „Z Ewangelii odczytywanej we wspólnocie kościelnej świadomość chrześcijańska nabyła poprzez pokolenia subtelnej wrażliwości i wyraźnego poznania zawartego $\mathrm{w}$ grzechu zarzewia śmier$c i$. Wrażliwości i zdolności poznania służącej także do wykrywania owego zarzewia w tysiącznych formach pochodzących z grzechu, w tysiącznych postaciach, w jakich się jawi. Chodzi tu o to, co zwykło się nazywać poczuciem grzechu" (RP 18).

${ }^{15} \mathrm{Nie}$ ulega wątpliwości, że ludzki grzech i wina z nim związana są wciąż obecne w historii ludzkości. „Prototypowe przykłady grzechu, zapisane w Księdze Rodzaju (nasi pierwsi rodzice, Kain, wieża Babel), nadal rzucają światło na sytuację człowieka. Choć za grzech odpowiedzialna jest zawsze jednostkowa osoba ludzka, to ogromne zło społeczne współczesnego świata stanowi dowód na przerażającą solidarność w grzechu" - A. Dulles, Blask wiary, s. 168.
} 
Boga oraz zagłuszanie sumienia zawsze będzie wielkim nieporządkiem moralnym we współczesnym świecie.

Rozwijanie się tego zjawiska w naszych czasach ma związek $\mathrm{z}$ funkcjonowaniem współczesnej kultury. Dobrze zinterpretowana dynamika jej zmian może dopomóc $\mathrm{w}$ zrozumieniu stopniowego zmniejszania się poczucia grzechu, przede wszystkim z powodu ujawniającego się lawinowo kryzysu sumienia i odrzucania Boga ${ }^{16}$. Na skutek zależności od laickiej etyki, która relatywizuje normę moralną, neguje się obecnie ,jej absolutną i bezwarunkową wartość i w konsekwencji negując istnienie aktów niegodziwych z natury, niezależnie od okoliczności, w jakich zostaną spełnione" (RP 18). Skutkiem takiego przewrotu etycznego jest zawsze osłabienie znaczenia grzechu do tego stopnia, że przyznaje się, iż grzech istnieje, ale nie wiadomo, kto go popełnia.

Zanika wreszcie poczucie grzechu wówczas, gdy w środkach społecznego przekazu, oraz w wychowaniu rodzinnym, bywa ono błędnie utożsamiane $\mathrm{z}$ chorobliwym poczuciem winy czy też ze zwykłym przekroczeniem norm i przepisów prawnych. Dlatego św. Jan Paweł II uważał, że przywrócenie właściwego poczucia grzechu jest pierwszym sposobem przezwyciężenia poważnego kryzysu duchowego, jaki trapi człowieka naszych czasów. Poczucie grzechu odbuduje się jednak jedynie przez jasne odwołanie się do niezmiennych zasad rozumu i wiary, zawsze głoszonych przez naukę moralną Kościoła (por. RP 18).

\section{KONIECZNOŚĆ ZWALCZANIA WYKROCZEŃ MORALNYCH}

Grzeszność człowieka ma wielorakie postacie i wciąż jest katalogiem otwartym, dlatego wszelkie próby systematyzacji grzechów są zawodne, chociaż są obszary, które należy dobrze rozpoznać ${ }^{17}$. Niebezpieczne jest powszechne we

${ }^{16}$ Por. M. ZAJĄC, Wychowanie sumienia na podstawie lubelskich podręczników do nauczania religii, w: Być człowiekiem sumienia. Interdyscyplinarny namyst nad fenomenem sumienia, red. R. Ceglarek, M. Sztaba, Częstochowa 2015, s. 291-315.

17 „Dlatego też, wysłuchawszy w tej sprawie zdania Kongregacji Nauki Wiary, Kongregacji ds. Kultu Bożego i Dyscypliny Sakramentów oraz Papieskiej Rady ds. Interpretacji Tekstów Prawnych, jak również czcigodnych Braci Kardynałów przewodniczących dykasterii Kurii Rzymskiej, potwierdzając naukę katolicką odnośnie do Sakramentu Pokuty i Pojednania ujętą syntetycznie w Katechizmie Kościoła Katolickiego" - JAN PAWEŁ II, List apostolski w formie „motu proprio" Misericordia Dei o niektórych aspektach sprawowania sakramentu pokuty (7.04.2002), Wstęp, AAS 94 (2002), s. 452-459. 
współczesnym świecie stępienie wrażliwości na dobra duchowe, które charakteryzuje się ociężałością religijną w pełnieniu obowiązków stanu i zawodu ${ }^{18}$. Może to pochodzić zarówno ze zwyczajnego zaniedbywania lub może być skutkiem popadnięcia w zobojętnienie duchowe. Prawdziwe niebezpieczeństwo pojawia się wówczas, gdy zmienia się kierunek zaangażowania woli ludzkiej, a w miejscu dotychczasowych pragnień duchowych pojawia się zmysłowość i rezygnacja z wyższych ideałów. Spowodowane to jest nie samymi trudnościami rozwoju, ale przeżywaniem nudy w życiu duchowym, gdzie brakuje już entuzjazmu wewnętrznego lub pojawia się smutek za porzuconym rozrywkowym stylem życia, pozbawionym wszelkich moralnych zobowiązań. Kiedy taki stan utrzymuje się dłużej, następuje utrata poczucia, że czyni się coś złego i nie jest potrzebne żadne nawrócenie. $\mathrm{W}$ takim stanie ducha znajduje się obecnie wielu chrześcijan, a ich liczba nieustannie się zwiększa ${ }^{19}$.

Gdy sytuacja jest w takim stanie, same zachęty do gorliwości są bezskuteczne, podobnie jak wskazywanie na piękne wzory np. świętych patronów i heroicznych postaci z dziejów, czy choćby współczesnych świętych, bo właśnie zło polega na odczuwaniu odrazy do wszelkiej gorliwości ${ }^{20}$. Ludziom, którzy żyją w pewnej atmosferze lekkomyślności, pochłaniającej ich całkowicie i wytwarzającej złe nawyki, trzeba zmienić ogólne warunki bytowania, a zwłaszcza codzienny tryb życia ${ }^{21}$. Przez sumienne spełnianie obowiązków stanu, dokładne przeprowadzenie ćwiczeń religijnych, powstrzymywanie się od rozpraszających duchowo rozrywek (np. fascynowanie się zawodami sportowymi, grami komputerowymi, stałe siedzenie wieczorami przy komputerze), wprowadza się ponownie opanowanie siebie, swoich poruszeń zmysłowych i przesadnego zainteresowania światem zewnętrznym ${ }^{22}$.

\footnotetext{
${ }^{18}$ Pomimo innych tendencji we współczesnym świecie niewrażliwym na grzech Katechizm Kościoła Katolickiego zawiera fundamentalna naukę: „W głębi sumienia człowiek odkrywa prawo, którego sam sobie nie nakłada, lecz któremu winien być posłuszny i którego głos wzywający go zawsze tam, gdzie potrzeba, do miłowania i czynienia dobra a unikania zła, rozbrzmiewa w sercu nakazem"- KKK 1776.

${ }^{19}$ Por. S. KULPACZYŃSKI, 25 opinii katechetów o 25 latach katechezy w szkole, w: XXV lat nauczania religii w polskiej szkole. Między nadzieja a rzeczywistościa, red. M. Zając, Lublin 2015, s. 214.

${ }^{20}$ Zob. J. WARZESZAK, Antropologia Benedykta XVI na tle blędnych antropologii wspótczesnych, „Warszawskie Studia Teologiczne” 27(2014), z. 2, s. 173.

${ }^{21}$ Zob. Kongregacja Instytutów Życia Konsekrowanego i Stowarzyszeń Życia ApoSTOLSKIEGO, Rozpoczać na nowo od Chrystusa, Poznań 2002, nr 11, s. 16.

${ }^{22}$ Por. K. ŚwIĘs, Szkolne nauczanie religii w odbiorze spolecznym, w: XXV lat nauczania religii w polskiej szkole, s. 231.
} 
Warto zaznaczyć, że grzech jest pojęciem teologicznym, oznaczającym wyraźne zaburzenie przez wolny i świadomy czyn człowieka obiektywnego porządku Bożego istniejącego w świecie. Doświadczenie grzechu jest doświadczeniem interpersonalnym, w którym można odnaleźć aspekty poznawcze, uczuciowe, motywacyjne, behawioralne ${ }^{23}$. Jednakże analiza grzechu lub poczucia winy nigdy nie powinna ograniczyć się tylko do procesów psychologicznych przebiegających wewnątrz człowieka. Należy iść dalej i określić warunki oraz czynniki sprzyjające różnym postawom grzesznym. Charakter grzechu jest ukształtowany przez socjoekonomiczną i polityczną strukturę danego społeczeństwa $^{24}$. Religijność społeczeństwa utrzymywanego w zależności będzie miała charakter autorytatywny, a zatem głównym grzechem człowieka będzie przede wszystkim nieposłuszeństwo wobec autorytetu boskiego, a drugorzędnie pogwałcenie norm etycznych ${ }^{25}$. Warto wiedzieć również, że istnieje katalog motywów skłaniających człowieka najpierw do wyboru grzechu, a następnie do szukania sposobów wygaszenia poczucia winy. Można do nich zaliczyć lęk przed utratą życia lub innych ważnych dla jednostki wartości, kiedy grzech jest szansą zachowania siebie lub tych wartości, ucieczkę od określonego bólu fizycznego, psychicznego, a nawet moralnego, oraz postawę roszczeniową idącą w parze z pychą ${ }^{26}$.

Nie wolno pominąć milczeniem także procesu kuszenia do grzechu, który osłabia zdolność do nawrócenia, gdzie zaangażowane są znaczące siły zła. Groźne skutki powoduje grzech w sferze moralnej człowieka, ponieważ jako osobowy akt sprzeciwu wobec Boga wnosi w życie moralne szczególną tonację, która w istocie swej polega na zaprzeczeniu wymagań w miłości, jaka ma prawo do ludzkiego serca ${ }^{27}$.

Ten proces rozwija się na zasadzie pięciu stopni: sugestia, rozmowa, walka, zgoda, namiętnośc ${ }^{28}$. Opis etapów tego procesu jest następujący. Najpierw pojawia się sugestia, czyli pokusa, kiedy człowiek stwierdza, że istnieje możliwość uczynienia zła, które zawsze jawi się w formie pociągającej. Kiedy pokusa nie jest odrzucona, może pociągnąć za sobą całą lawinę zła. Następnie

${ }^{23}$ R. JAWORSKI, Obciążenie grzechem, w: Rozwój zintegrowany, red. R. Jaworski, Płock 2002, s. 99.

${ }^{24}$ Por. K. ŚwIĘS, Przemiany religijności miejskiej w czasie transformacji ustrojowej, Lublin 2011, s. 221 n.

${ }^{25}$ Tamże.

${ }^{26}$ Por. M. Wolicki, Doświadczenie grzechu, w: Podstawowe zagadnienia psychologii religii, red. S. Głaz, Kraków 2006, s. 318.

${ }^{27}$ S. Rosik, Grzech, w: Katolicyzm A-Z, red. Z. Pawlak, Poznań 1982, s. 178

${ }_{28}$ Por. J. GoGOLA, Grzech: przyczyny i konsekwencje dla życia duchowego, http://www.karmel.pl/ lektorium/publikacje/baza.php?id=30 (dostęp 3.11.2015). 
pojawia się tzw. rozmowa ze zła myśla. Ten etap dobrze obrazuje biblijna rozmowa Ewy z szatanem. Zwykle człowiek pozwala prowokować się i zaczyna dialogować z pokusą i zajmując myśli, serce przez dłuższy czas, traci duchową siłę, naraża się na upadek. Z kolei pojawia się walka. Myśl, która po długiej rozmowie skolonizowała serce, niełatwo daje się wyrzucić. Człowiek wprawdzie jest jeszcze wolny i może się im opierać, ale to wymaga trudu i walki. Potem przychodzi zgoda. Kto przegrał walkę z pokusą, decyduje się wykonać przy pierwszej okazji to, co sugeruje mu zła myśl. Na tym etapie popełnia się grzech i uruchamia proces uwalniania się od winy poprzez bagatelizowanie jego skutków. W końcu pojawia się etap zwany pasja, która charakteryzuje się skłonnością do grzechu oraz powtarzaniem tych samych czynów, podczas której powstaje w człowieku coraz większa łatwość przyzwolenia na grzech. Jak powtarzane dobro wyrabia sprawność do dobrego, tak powtarzane zło prowadzi do wad i nałogów, czy do zniewolenia i duchowej śmierci. Człowiek może dojść do takiego stanu zniewolenia, że nie będzie odczuwał odpowiedzialności za swoje czyny i nigdy się nie nawróci ${ }^{29}$.

Dlatego „aby móc zidentyfikować własną błędną postawę jako grzech, wymagane jest zdecydowanie odkrycia prawdy i gotowość słuchania głosu sumienia. Praktyczną drogą wychodzenia z postawy grzechu jest wejście na drogę odpowiednich cnót, przeciwstawiających się tym grzesznym postawom"30. Tylko doświadczenie przebaczenia i jego leczącej mocy może wyzwolić współczesnego człowieka z braku poczucia winy i rozbudzić autentyczne nawrócenie.

Nie wolno w kontekście prowadzonych rozważań zapominać jeszcze o jednym fakcie, który mógł wpłynąć na osłabienie poczucia winy oraz porzucenie praktyki nawrócenia i przebaczenia wśród chrześcijan. Oto katoliccy apologeci próbowali usprawiedliwiać to, co zostało uczynione w imieniu Kościoła. Częściowo z tego powodu Kościół był i jest obwiniany za wydarzenia z dalekiej przeszłości, których sprawcami nierzadko byli ludzie niewrażliwi na wymagania Ewangelii. Brak nazwania po imieniu grzechów z przeszłości zainfekował świadomość chrześcijan, którzy stosowali podobną analogię wobec swoich wykroczeń moralnych. Jednak szczere przyznanie się do winy Kościoła okazało się najlepszą strategią pozwalającą uleczyć wciąż żywe rany. Ewangelizacja w świecie współczesnym wymaga nowej apologetyki, zbudowanej na pokorze, uczciwości i miłości do tych, którzy jako jednostki i wspólnoty zostali zranieni przez katolików ${ }^{31}$. Program eklezjalnej skruchy jest zatem

\footnotetext{
${ }^{29}$ Tamże.

${ }^{30}$ R. JAWORSKI, Obcią̇̇enie grzechem, s. 102.

${ }^{31}$ A. Dulles, Blask wiary, s. 168.
} 
powiązany z wezwaniem do nawrócenia, które urasta do zadania strategicznego w funkcjonowaniu wspólnot eklezjalnych w naszych czasach.

\section{NAWRÓCENIE KONIECZNYM ELEMENTEM PRZEBACZENIA}

Wskazania Magisterium Kościoła są jednoznaczne co do warunków zewnętrznych korzystania z oferty odpuszczenia grzechów i brzmią; „Normy co do konfesjonału winny być ustanowione przez poszczególne Konferencje Episkopatu. Zagwarantują one, że konfesjonał będzie umieszczony «w miejscu widocznym» oraz że będzie «zaopatrzony w kratę», tak aby mogli z niego swobodnie korzystać pragnący tego wierni i sami spowiednicy" ${ }^{32}$. Jednakże w strategii przełamywania zaniku poczucia grzechu ważniejsze są osobiste doświadczenia penitentów związane z własnym nawróceniem i obdarowaniem Bożym miłosierdziem ${ }^{33}$.

Przebaczenie jako fenomen życia religijnego człowieka jest zasadniczo rzeczywistością teologiczną, ze względu na jego genezę i konsekwencje. Ale dokonuje się w osobowości człowieka w określonej grupie społecznej, dlatego także psychologia i socjologia mają prawo w pewnym zakresie wypowiadać się w tej kwestii. Przebaczenie związane z nawróceniem człowieka „nie jest akceptacją zła czy sprzyjaniem mu, ale rezygnacją z prawa zemsty i z nakręcania spirali nienawiści. Jest odrzuceniem agresywności, niezdrowej ambicji, wysokiego mniemania o sobie ${ }^{34}$. Przebaczenie w swojej najprawdziwszej i najwznioślejszej postaci jest zawsze aktem bezinteresownej miłości, która jednak bazuje na nawróceniu człowieka i apriorycznie je zakłada ${ }^{35}$.

Mając na uwadze sposób funkcjonowania jednostki ludzkiej, jej zdrowie psychiczne oraz duchowy rozwój, można zaryzykować twierdzenie, że przebaczenie jest w życiu człowieka potrójną koniecznością: teologiczną, psychologiczną i socjologiczną. Każdy człowiek potrzebuje przebaczenia od Boga ze

\footnotetext{
32 Por. kan. 964, § 2; PAPIESKA RADA DS. InTERPRETACJI TEKSTÓW PRAWNYCH, Responsio ad propositum dubium: de loco excipiendi sacramentales confessiones (7.07.1998), AAS 90 (1998), s. 711.

${ }^{33}$ Por. Benedykt XVI, Spowiedź sakramentalna siła nowej ewangelizacji. Przemówienie do uczestników kursu dla spowiedników (9.03.2012), „L’Osservatore Romano” 33(2012), nr 5, wyd. pol., s. 47-48.

${ }^{34}$ J. Naumowicz, O przebaczeniu i modlitwie, w: Krzywda i przebaczenie, red. T. Huk, A. Foltańska, Kraków 1997, s. 87.

35 „Pojednanie z drugim wymaga najpierw odkrycia w nim wspaniałości obrazu Boga. [...] W tej perspektywie zasadnicze znaczenie ma odróżnienie grzesznika od jego grzechu i jego przewinienia, aby osiągnąć prawdziwe pojednanie. Oznacza to, że nienawidzisz zła, które wyrządza ci drugi, ale nadal go kochasz, ponieważ uznajesz jego słabość i widzisz w nim obraz Boga” (ChV 165).
} 
względu na swoją grzeszność, co ostatecznie gwarantuje szczęście wieczne. Dlatego prośba o przebaczenie pojawia się tak często w modlitwach indywidualnych chrześcijan oraz wspólnoty Kościoła. Warto także i to nieustannie podkreślać, że Kościół nie tylko modli się o przebaczenie, ale także tego przebaczenia w imię Boże udziela certyfikując jednocześnie znaczenie osobistego nawrócenia człowieka ${ }^{36}$.

Bóg jednak uzależnił udzielenie przebaczenia od naszego nawrócenia i przebaczenia okazywanego bliźnim, którzy wyrządzili nam jakąkolwiek krzywdę. Jezus mówił o tym tak: „Jeśli wy nie przebaczycie ludziom, i Ojciec wasz nie przebaczy wam waszych przewinień" (Mt 6, 15). Dlatego przebaczenie okazywane bliźnim jawi się w świetle Ewangelii jako absolutna konieczność teologiczna. Jezus nie tylko zobowiązuje swoich wyznawców do przebaczenia, ale sam daje tego przykład, przebaczając tym, którzy Go krzyżowali i modląc się za nich. Dlatego uczniowie Jezusa, od początku wpatrzeni w przykład swego Mistrza, starali się wypełniać ten obowiązek przebaczenia. W naszych czasach wzruszający był gest przebaczenia św. Jana Pawła II w stosunku do tego, który chciał Go zabić, wpisujący się w ewangeliczną strategię naśladowania Jezusa ${ }^{37}$.

Nawrócenie jest także koniecznością teologiczną w tym sensie, że do prawdziwego i pełnego przebaczenia wielkich win i krzywd może uzdolnić tylko sam Bóg, udzielając człowiekowi swej łaski. Z reguły człowiek skrzywdzony w swych prawach domaga się zemsty oraz odwetu. Jedynie człowiek żyjący prawdziwym życiem Bożym jest zdolny do prawdziwego przebaczenia. W opinii M. Wolickiego przebaczenie, które wspiera się na autentycznym nawróceniu człowieka ,jest konieczne nie tylko z racji teologicznych, z troski o własne zbawienie, ale także jest konieczne z racji psychologicznych, jako warunek prawidłowego rozwoju i dojrzewania osoby ludzkiej" ${ }^{38}$. Nawrócenie połączone z przebaczeniem jest szansą dalszego rozwoju, bo jeżeli człowiek nie zdecyduje się na ten proces, utrwalają się w nim postawy rozgoryczenia i nie jest w stanie dokonać postępu na drodze rozwoju duchowego ${ }^{39}$. Doznana krzywda staje się jakby punktem zapalnym w ludzkiej osobowości, wokół którego zaczyna się

\footnotetext{
${ }^{36}$ Por. M. Wolicki, Doświadczenie przebaczenia, w: Podstawowe zagadnienia psychologii religii, red. S. Głaz, Kraków 2006, s. 322.

${ }^{37}$ Papieskie przebaczenie zaowocowało niezwykłym gestem zamachowca. Watykan potwierdził, że turecki zamachowiec Ali Agca, który ciężko zranił Jana Pawła II 13 maja 1981 roku, złożył kwiaty na jego grobie w bazylice Świętego Piotra. Agca uczynił to w 31. rocznicę rozmowy z papieżem w rzymskim więzieniu. Por. Watykan: Ali Agca przy grobie Jana Pawta II w bazylice, http://wiadomosci. onet.pl/swiat/watykan-ali-agca-przy-grobie-jana-pawla-ii-w-bazylice/7dqjw (dostęp 3.11.2015).

${ }^{38}$ M. Wolicki, Doświadczenie przebaczenia, s. 324.

${ }^{39}$ R. JAWORSKI, Przebaczenie szansa rozwoju, w: Rozwój zintegrowany, red. R. Jaworski, Płock 2002, s. 158.
} 
kręcić wszystko. Jeśli skrzywdzony człowiek nie przerwie tej pętli i nie zdobędzie się na przebaczenie, jego dalszy rozwój zostanie zablokowany, a nawet uniemożliwiony ${ }^{40}$. Dlatego „wybaczenie komuś to prezent darowany wyłącznie samemu sobie. Człowiek, który przebacza, odnosi korzyść, bo może wreszcie wyjąć cierń ze swojej duszy"41. Uzdrowienie wewnętrzne dokonuje się z jednej strony przez przebaczenie i pojednanie, $\mathrm{z}$ drugiej zaś przez podejmowanie coraz pełniejszej odpowiedzialności za własne życie we współpracy z Bożą łaską.

Nawrócenie, które umożliwia przebaczenie jest konieczne także z racji społecznych. Bez przebaczenia nie będzie możliwe nawiązywanie pozytywnych więzi społecznych, prowadzenie autentycznego dialogu, pełnienie funkcji społecznych. Dzieje się tak dlatego, że egzystencja człowieka w świecie dotyka dwóch rzeczywistości: materialnej i duchowej ${ }^{42}$. Toteż umiejętność nawrócenia jest szczególnie konieczna u tych, którzy z racji swego zawodu muszą posiadać zdolność przebaczania. Trzeba tu mieć na myśli rodziców, pedagogów, kapłanów, policjantów, polityków. Jest rzeczą jasną, że przezwyciężenie doświadczenia skrzywdzenia jest szczególnie ważne dla tych, którzy pragną nieść posługę przebaczenia i pojednania między ludźmi ${ }^{43}$ Człowiek, który ma być szafarzem Bożego miłosierdzia, musi zdobywać się na przebaczenie wobec samego siebie i innych ludzi ${ }^{44}$.

Brak poczucia winy u człowieka przekraczającego normy moralne powoduje syndrom „reakcji łańcuchowej”, polegający na tym, że ludzie skrzywdzeni, którzy nie potrafią przebaczyć, i nie doznają przebaczenia najczęściej krzywdzą innych. Dlatego im wcześniej człowiek podejmie pracę nad swoimi zranieniami związanymi z właściwym pojmowaniem grzechu, tym łatwiej może je w sobie

\footnotetext{
40 Tamże, s. 154.

${ }^{41}$ J. Mellibruda, Pułapka nie wybaczonej krzywdy, Warszawa 2009, s. 19.

${ }^{42}$ Św. Jan Paweł II w encyklice Dominum et vivificantem przekonywał, że w sytuacji, kiedy sumienie uformowane jest poprawnie, wtedy „osoby i grupy ludzkie unikają ślepej samowoli i starają się dostosowywać do obiektywnych norm moralności. Taka postawa w konsekwencji skutkuje deeskalacją napięć między poszczególnymi ludźmi, wspólnotami - nie tylko eklezjalnymi, bądź nawet do uniknięcia konfliktu zbrojnego. Nie wolno bowiem nikomu narzucać własnej prawdy. Prawda zwycięża tylko własną mocą. Narzucanie własnych poglądów prowadzi do zaostrzenia stosunków międzyludzkich, powstania sprzeczności i napięć. Stąd warunkiem zachowania pokoju w świecie jest poszanowanie wolności sumienia innych ludzi, nawet jeśli myślą zupełnie inaczej”- DeV 43.

${ }^{43}$ J. Augustyn, Wstęp, w: Krzywda i przebaczenie, red. T. Huk, A. Foltańska, Kraków 1997, s. 7.

${ }^{44}$ Por. M. ZAJĄC, Wychowanie sumienia na przykładzie lubelskich podręczników do nauczania religii, w: Być człowiekiem sumienia. Interdyscyplinarny namyst nad fenomenem sumienia, red. R. Ceglarek, M. Sztaba, Częstochowa 2015, s. 315.
} 
uleczyć. Bez nawrócenia i umiejętności przebaczenia nie ma prawdziwej wspólnoty międzyludzkiej, tym bardziej wspólnoty chrześcijańskiej. Dlatego zdolność do przebaczenia oparta na sztuce nawrócenia jest znakiem autentyzmu naszego życia chrześcijańskiego, świadomości przynależenia do jednej rodziny dzieci Bożych i właściwego rozumienia swojej odpowiedzialności przed Bogiem.

\section{BIBLIOGRAFIA}

Augustyn, Jerzy, Wstęp, w: Krzywda i przebaczenie, red. T. Huk, A. Foltańska, Kraków 1997, s. 7-10.

BENEDYKT XVI, Spowiedź sakramentalna siłą nowej ewangelizacji. Przemówienie do uczestników kursu dla spowiedników, „L’Osservatore Romano” 33(2012), nr 5, wyd. pol., s. 47-48.

ChACHULSKI, Tomasz, SNOPEK, Jerzy, ŚLuSARSKA, Magdalena (red.), Religijność w dobie popkultury, Warszawa 2014.

Dulles, Avery, Blask wiary. Wizja teologiczna Jana Pawła II, tłum. A. Nowak, Kraków 2003.

GŁAZ, Stanisław red., Podstawowe zagadnienia psychologii religii, Kraków 2006.

GoGOLA, Jerzy, Grzech: przyczyny i konsekwencje dla życia duchowego, http://www.karmel.pl/ lektorium/publikacje/baza.php?id=30 (dostęp 3.11.2015).

Huk, Tadeusz, FoltańsKA, Anna. (red.), Krzywda i przebaczenie, Kraków 1997.

JAN PAWE€ II, Adhortacja apostolska o pojednaniu i pokucie w dzisiejszym posłannictwie Kościoła Reconciliatio et paenitentia (2.12.2007), AAS 77 (1985), s. 185-275.

JAN PAWEŁ II, List apostolski w formie "motu proprio" Misericordia Dei o niektórych aspektach sprawowania sakramentu pokuty (7.04.2002), Wstęp, AAS 94 (2002), s. 452-459.

JASNOS, A., Mój Bóg, Lublin 2020.

JAWORSKI, Romuald, Obciążenie grzechem, w: Rozwój zintegrowany, red. R. Jaworski, Płock 2002, s. 99-103

JAWORSKI, Romuald (red.), Rozwój zintegrowany, Płock 2002.

Kongregacja Instytutów Życia Konsekrowanego i Stowarzyszeń Życia Apostolskiego, Rozpocząć na nowo od Chrystusa, Poznań 2002.

KULPACZYŃSKI, Stanisław, 25 opinii katechetów o 25 latach katechezy w szkole, w: XXV lat nauczania religii w polskiej szkole. Między nadzieją a rzeczywistością, red. M. Zając, Lublin 2015, s. 205-227.

LASCONi, Tonino, Ja i Ty przez 365 dni (+1), thum. K. Wilewska, Poznań 2007.

MĄкosA, Paweł, Między katolicką ortodoksją a indywidualizacją wierzeń dorosłych Polaków, w: Katechetyk i wychowawca, Warszawa 2019, s. 293-306.

MellibrudA, Jerzy, Pułapka nie wybaczonej krzywdy, Warszawa 2009.

NAGÓRNY, Janusz, Zanik poczucia grzechu w świecie współczesnym, „Kurier Synodalny” 22(1996), nr 1, s. 10-15.

NAUMOWICZ, Józef, O przebaczeniu i modlitwie, w: Krzywda i przebaczenie, red. T. Huk, A. Foltańska, Kraków 1997, s. 87-102.

PAPIESKA KOMISJA BiBLIJNA, Biblia a moralność. Biblijne korzenie postępowania chrześcijańskiego, tłum. R. Rubinkiewicz, Kielce 2009. 
PAPIESKa RADA DS. InTERPRETACJI TeKStÓw PRAWNyCh, Responsio ad propositum dubium: de loco excipiendi sacramentales confessiones (7.07.1998), AAS 90 (1998), s. 711.

RAHNER, Karl, VORGRIMLER Herbert, Mały słownik teologiczny, tłum. T. Mieszkowski, P. Pachciarek, Warszawa 1987.

Rosik, Seweryn, Grzech, w: Katolicyzm A-Z, red. Z. Pawlak, Poznań 1982, s. 178-179.

SNOPEK, Jerzy, Wstęp, w: Religijność w dobie popkultury, red. T. Chachulski, J. Snopek, M. Ślusarska, Warszawa 2014, s. 5-9.

SzUBARTOwSKA, Alicja, Zmiana kodu kulturowego młodzieży wyzwaniem dla katechety szkolnego, w: Katecheza w szkole współczesnej, red. M. Zając, Lublin 2010, s. 45-64.

ŚwIĘS, Kazimierz, Przemiany religijności miejskiej w czasie transformacji ustrojowej, Lublin 2011.

ŚwIĘS, Kazimierz, Szkolne nauczanie religii w odbiorze społecznym, w: XXV lat nauczania religii w polskiej szkole. Między nadzieja a rzeczywistością, red. M. Zając, Lublin 2015, s. 229-240.

WARZESZAK, Józef, Antropologia Benedykta XVI na tle błędnych antropologii współczesnych, „Warszawskie Studia Teologiczne” 27(2014), z. 2, s. 173-192.

Wolicki, Marian, Doświadczenie przebaczenia, w: Podstawowe zagadnienia psychologii religii, red. S. Głaz, Kraków 2006, s. 317-318.

ZAJĄC, Marian, Wychowanie sumienia na przykładzie lubelskich podręczników do nauczania religii, w: Być człowiekiem sumienia. Interdyscyplinarny namysł nad fenomenem sumienia, red. R. Ceglarek, M. Sztaba, Częstochowa 2015, s. 291-315.

\title{
NAWRÓCENIE JAKO WARUNEK POJEDNANIA Z BOGIEM
}

\author{
Streszczenie
}

Niniejszy artykuł wyrasta $\mathrm{z}$ narracji zawartej w posynodalnej adhortacji apostolskiej Reconcilatio et paenitentia św. Jana Pawła II, który zdecydowanie przestrzegał chrześcijan przed utratą poczucia grzechu. Praca składa się z trzech proporcjonalnych części. W części pierwszej zostaną zaprezentowane wiodące przyczyny utraty poczucia grzechu we współczesnym świecie oraz strategia katechetyczna, która nawołuje do odróżnienie grzesznika od jego grzechu i jego przewinienia, aby osiągnąć prawdziwe pojednanie. W części drugiej zostanie podjęta próba uzasadnienia konieczności zwalczania wykroczeń moralnych, mogących pochodzić zarówno ze zwyczajnego zaniedbywania albo być skutkiem zobojętnienia duchowego. Zostanie wyjaśnione, że grzech to wyraźne zaburzenie przez wolny i świadomy czyn człowieka obiektywnego porządku Bożego istniejącego w świecie, oraz podkreślony fakt, że wciąż istnieje proces kuszenia do grzechu przez znaczące siły zła, a ten osłabia zdolność do nawrócenia. Zostanie także opisany pięciostopniowy proces pogrążania się w rzeczywistości grzechu. W części trzeciej zostanie wyjaśnione, dlaczego nawrócenie osobiste człowieka jest koniecznym elementem przebaczenia. Chociaż do prawdziwego przebaczenia win i krzywd może uzdolnić tylko Bóg, udzielający człowiekowi swej łaski, to jednak przebaczenie jest konieczne jako warunek prawidłowego rozwoju i dojrzewania osoby ludzkiej. Artykuł zakończą informacje, że bez nawrócenia i umiejętności przebaczenia nie ma prawdziwej wspólnoty międzyludzkiej, tym bardziej wspólnoty chrześcijańskiej.

Słowa kluczowe: nawrócenie; pojednanie; grzech; Bóg. 